\title{
Review \\ Adhesion Molecule Targeted Therapy for Non-Infectious Uveitis
}

\author{
Yi-Hsing Chen ${ }^{1,2,3}$, Sue Lightman ${ }^{1}$, Malihe Eskandarpour ${ }^{1}$ and Virginia L. Calder ${ }^{1,4, *}$ \\ 1 UCL Institute of Ophthalmology, University College London, London EC1V 9EL, UK; \\ yi-hsing.chen.14@alumni.ucl.ac.uk (Y.-H.C.); s.lightman@ucl.ac.uk (S.L.); m.eskandarpour@ucl.ac.uk (M.E.) \\ 2 Department of Ophthalmology, Chang Gung Memorial Hospital, Taoyuan 333, Taiwan \\ 3 College of Medicine, Chang Gung University, Taoyuan 333, Taiwan \\ 4 NIHR Biomedical Research Centre at Moorfields Eye Hospital NHS Foundation Trust, London EC1V 2PD, UK \\ * Correspondence: v.calder@ucl.ac.uk
}

check for updates

Citation: Chen, Y.-H.; Lightman, S.; Eskandarpour, M.; Calder, V.L. Adhesion Molecule Targeted Therapy for Non-Infectious Uveitis. Int. J. Mol. Sci. 2022, 23, 503. https://doi.org/ $10.3390 /$ ijms 23010503

Academic Editors: Hiroshi Keino, Junko Hori and Takefumi Yamaguchi

Received: 3 November 2021

Accepted: 11 December 2021

Published: 3 January 2022

Publisher's Note: MDPI stays neutral with regard to jurisdictional claims in published maps and institutional affiliations.

Copyright: () 2022 by the authors Licensee MDPI, Basel, Switzerland. This article is an open access article distributed under the terms and conditions of the Creative Commons Attribution (CC BY) license (https:// creativecommons.org/licenses/by/ $4.0 /)$.

\begin{abstract}
Non-infectious uveitis (NIU) is an inflammatory eye disease initiated via $\mathrm{CD} 4^{+}{ }^{\mathrm{T}}$-cell activation and transmigration, resulting in focal retinal tissue damage and visual acuity disturbance. Cell adhesion molecules (CAMs) are activated during the inflammatory process to facilitate the leukocyte recruitment cascade. Our review focused on CAM-targeted therapies in experimental autoimmune uveitis (EAU) and NIU. We concluded that CAM-based therapies have demonstrated benefits for controlling EAU severity with decreases in immune cell migration, especially via ICAM1/LFA-1 and VCAM-1/VLA-4 (integrin) pathways. P-selectin and E-selectin are more involved specifically in uveitis related to vasculitis. These therapies have potential clinical applications for the development of a more personalized and specific treatment. Localized therapies are the future direction to avoid serious systemic side effects.
\end{abstract}

Keywords: adhesion molecule; integrin; lymphocyte function-associated antigen-1 (LFA-1); very late antigen-4 (VLA-4); uveitis; experimental autoimmune uveitis; non-infectious uveitis; intercellular cell adhesion molecule-1 (ICAM-1); vascular cell adhesion protein 1 (VCAM-1); selectin

\section{Introduction}

Non-infectious uveitis (NIU) describes a broad disease spectrum involving inflammation in the pigmented middle layer of the eye (uvea) driven by autoimmune and autoinflammatory pathways [1,2]. Epidemiologically, NIU has a higher prevalence in people of working age, and a significant socioeconomical impact [3,4]. Pathologically, this intraocular inflammation is mediated via antigen-specific $\mathrm{CD}^{+} \mathrm{T}$ cells becoming activated, which then proliferate centrally and migrate into the eye. As a result of this, inflammatory myeloid cells are recruited and contribute to the retinal structural damage and final vision disturbance [5].

Recruitment of activated effector $\mathrm{CD} 4^{+} \mathrm{T}$ cells to the immune reaction site involves a well-defined cascade, beginning with capturing freely moving leukocytes to the endothelium, which roll before adhering to endothelial cells, undergoing post-adhesion strengthening, being activated, crawling, and transmigrating across the endothelium. During the steps of the leukocyte recruitment cascade, a distinct set of adhesion molecules is activated to fine-tune the process temporally and spatially [6,7]. Cell adhesion molecules (CAM) are glycoproteins expressed on the cell surface and include the integrin family, the immunoglobulin superfamily, selectins, and cadherins [8]. In this review, it was noticed that the involvement of integrins, selectins, and cadherins was mainly reported in uveitis [9]. Integrin assembly constitutes obligate noncovalently bound heterodimers. In mammals, subunits of $18 \alpha$ and $8 \beta$ integrins within the integrin family have been identified to form 24 different integrin heterodimers [10]. Among the leukocyte subsets, it is known that neutrophils express mostly $\beta 2$-integrins with a few $\beta 1$ - and $\beta 3$-integrins. Monocytes mainly express $\beta 1$ - and $\beta 2$-integrins, whereas lymphocytes predominantly express $\beta 1-, \beta 2-$, and 
$\beta 7$-integrins varying by the state of activation and their subtype. Specifically, leukocytes express heterodimeric integrins including $\alpha \mathrm{L} \beta 2$ (lymphocyte function-associated antigen1 (LFA-1), CD11a/CD18), $\alpha \mathrm{M} \beta 2$ (macrophage antigen-1 (Mac-1), CD11b/CD18), $\alpha$ X $\beta 2$, $\alpha \mathrm{D} \beta 2, \alpha 4 \beta 1$ (very late antigen-4 (VLA-4), CD49d/CD29), and $\alpha 4 \beta 7$. Along with other adhesion molecules, such as selectin, intercellular cell adhesion molecule-1 (ICAM-1), and vascular cell adhesion protein 1 (VCAM-1), these molecules govern immune cell migration to sites of inflammation and T-cell-mediated immunity in tissues [6].

The importance of CAMs involved differentially in the pathways of many autoimmune diseases has been validated by selectively targeting integrins for clinical use and monitoring their clinical efficacy. For example, in another immune-mediated central nervous system disease, multiple sclerosis, natalizumab (monoclonal antibody to heterodimer of $\alpha 4 \beta 7$ and $\alpha 4 \beta 1$ ) has been an FDA-approved treatment since 2004 [11]. The therapeutic effect of natalizumab has been shown to occur via blockade of $\alpha 4 \beta 1$ - rather than $\alpha 4 \beta 7$-integrin. This is supported by the fact that antibodies against $\alpha 4 \beta 7$ heterodimer or $\beta 7$-integrin fail to downregulate disease [12]. Furthermore, endothelial overexpression of mucosal vascular addressin cell-adhesion molecule 1 (MAdCAM- 1 , the counter-receptor of $\alpha 4 \beta 7$-integrin) does not correlate with experimental autoimmune encephalomyelitis (EAE) severity [13]. On the other hand, $\alpha 4 \beta 7$ is the main integrin involved in ulcerative colitis and Crohn's disease. It is substantiated by evidence that anti- $\alpha 4 \beta 7$ antibodies (Vedolizumab, Millennium Pharmaceuticals) can prevent T cells binding to MAdCAM-1 in the mucosal vasculature and thus were approved by the FDA for use in ulcerative colitis and Crohn's disease in 2014 [14,15]. The major side effects from using systemic anti-integrin therapies are progressive multifocal leukoencephalopathy (PML) and reactivation of John Cunningham (JC) virus infection, which are both serious and potentially fatal $[14,16]$. These have been reported with the use of natalizumab and efalizumab (from Raptiva and Genentech, respectively), a humanized monoclonal antibody to the alpha chain (CD11a) of the $\beta 2$-integrin LFA-1 [14,16]. The side effect to natalizumab was proposed by targeting $\alpha 4 \beta 1$ [14].

The increased expression of CAMs during uveitis has been demonstrated in histopathological specimens in humans [17-20]. Blocking these pathways has been shown to be effective to treat some ocular diseases. In allergic conjunctivitis, levocabastine, an antihistamine eyedrop, has been reported to suppress inflammation via downregulating $\alpha 4 \beta 1$ expression at the conjunctival level [21]. Lifitegrast, a topically administered LFA-1 antagonist, has been reported to inhibit binding between T cells and ICAM-1, thus alleviating $\mathrm{CD}^{+}$-T-cell-mediated dry eye symptoms and was approved for use by the FDA in 2016. It demonstrated a comparative treatment effect to topical cyclosporin A, a potent T-cell activation inhibitor [22,23]. There have been local side effects reported, such as eye irritation, dysgeusia, and reduced visual acuity. However, no systemic side effects have been observed [23], hence the rationale for anti-CAM therapy, specifically anti-integrin therapy, being used for another ocular inflammatory disease, NIU. There have been some reports using anti-integrin therapy in experimental autoimmune uveitis (EAU), an animal model used to study NIU. This review focuses on the role of anti-CAM therapy in uveitis using EAU models and provides new clinical insights.

\section{Material and Methods}

This review includes published articles on the pharmaceutical efficacy of targeting adhesion molecules for NIU and EAU, including phase 2 and phase 3 clinical trials and review papers. We performed a search on PubMed for the peer-reviewed literature available using the MeSH terms "integrin," “ $\alpha 4 \beta 1$," “ $\alpha 4 \beta 7$," “ $\alpha \mathrm{V} \beta 3$," “ $\alpha \mathrm{V} \beta 5$," “ $\alpha \mathrm{V} \beta 1$," “VLA-4,” "LFA-1," "ICAM-1," "vascular cell adhesion protein 1 (VCAM-1)," "selectin," "uveitis," and/or "clinical trials." We did not set for language limitations. The search was undertaken for published manuscripts addressing integrin-related pathophysiology in NIU, EAU, and relevant clinical trials until June 2021.

The primary search identified 339 records for the MeSH terms mentioned above and one extra record was recruited from http:/ / clinicaltrial.gov/ (29 June 2021). A total of 
254 records, which failed to meet the inclusion criteria (irrelevant to uveitis but other systemic autoimmune disease, $n=42)$ or were duplicated $(n=212)$ between the searches, were excluded (29 June 2021). Next, 85 full-text articles were assessed for eligibility, from which 67 studies were selected for qualitative synthesis and were included in the study. Two researchers (Y.-H.C., V.C.) identified the 67 published studies that met the inclusion criteria. A description of the full identification process is summarized in Figure 1.

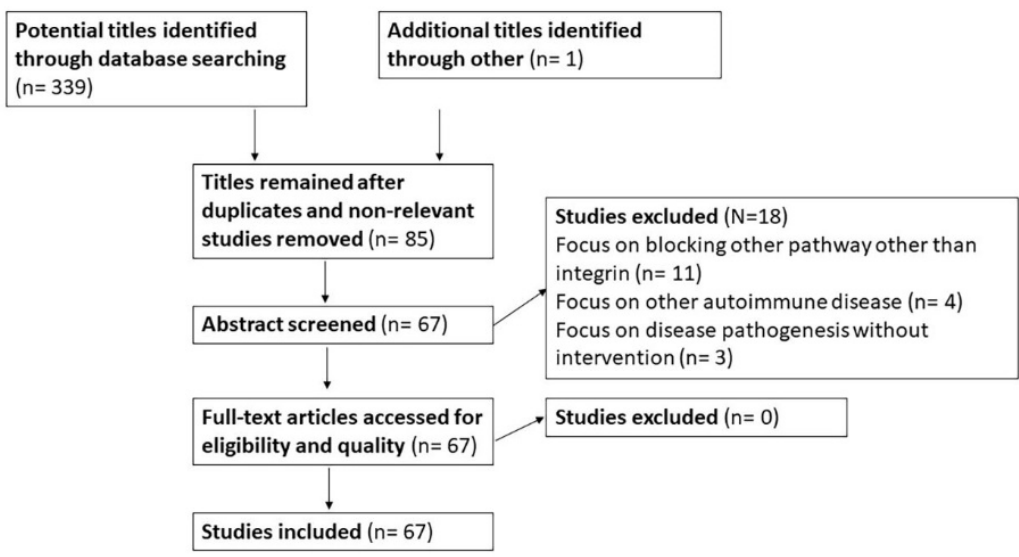

Figure 1. A PRISMA flow diagram depicting information through the different phases of this review.

\section{Results}

\subsection{Role of Cell Adhesion Molecules in Experimental Autoimmune Uveitis}

Differential expression of CAMs during EAU has been reported. In EAU models, the most addressed CAMs are ICAM-1 and its ligand (LFA-1; a $\beta 2$-integrin). Basal retinal expression of ICAM-1 is detectable before intraocular inflammation and the level rises one to two days prior to the clinical manifestation of EAU [24]. This is supported by in vitro evidence that ICAM-1 is constantly expressed on retinal pigment epithelium (RPE), and its expression level is upregulated after inflammation is induced [25-27]. LFA-1 is reported to be expressed on $40 \%$ of uveitogenic $\mathrm{CD}^{+} \mathrm{T}$ cells and $60 \%$ of non-CD4 ${ }^{+} \mathrm{T}$ cells at the early stages of the EAU model in C57BL/ 6 mice (day 12), and its level is upregulated throughout the course of EAU $[28,29]$. Both ICAM-1 and LFA-1 inhibitors can prevent effector T cells from migrating into the retinae in vivo and reduce clinical EAU severity [29-31]. In vitro assays further demonstrated that anti-ICAM-1 antibody blocked non-uveitogenic, polarized Th1 and Th17 cell transmigration at similar levels across the human retinal endothelial cell (REC) monolayer in a Boyden chamber [32]. The effect of anti-LFA-1 antibody was reported to bypass $\mathrm{CD}^{+}$regulatory $\mathrm{T}$ cells (Tregs) $[31,33]$. In an ocular surface disease mouse model, it was demonstrated that an LFA-1 antagonist (Lifitegrast) downregulated clinical dry eye severity via preferentially blocking Th1 cell migration [34].

On the other hand, although VCAM-1 is expressed neither in healthy retinal tissues nor on unstimulated retinal barrier cells in vitro, its expression is induced and upregulated on RECs and RPEs during inflammation [25-27]. The expression of VLA-4 ( $\alpha 4 \beta 1$ integrin), the ligand to VCAM-1, has been reported mostly in non-CD4 ${ }^{+} \mathrm{T}$ cells and rarely ( $\left.2 \%\right)$ on uveitogenic $\mathrm{CD}^{+} \mathrm{T}$ cells during the early stages of EAU in C57BL/6 mice [28]. Our data demonstrated that at peak classical EAU in B10.RIII mice, there was an equal expression (30 40\%) of VLA-4 by both Th1 and Th17 cells [35]. The increase in VLA-4 expression by $\mathrm{CD}^{+} \mathrm{T}$ cells was confined to the draining lymph nodes and the eye, but not the peripheral blood, suggesting that pathogenic leukocytes expressing VLA-4 are only present at local sites of inflammation [35,36]. This is supported by an in vitro study showing that antibody to VCAM-1 does not affect activated non-uveitogenic Th1 and Th17 cell migration [32]. Targeting VLA-4 is able to block the recruitment and migration of uveitogenic $\mathrm{T}$ cells and monocytes across the blood-retinal barrier (BRB), which ameliorates EAU development without affecting systemic immunity. A recent study reported that a small molecule 
inhibiting VLA-4 ameliorated the clinical signs of EAU by preferentially suppressing Th17 cell and inflammatory monocyte transmigration across the eye [35]. In addition, the effects of targeting VLA-4 and LFA-1 were reported to be transient and continuous treatment is needed [33]. It has been shown that natalizumab (less than $1.25 \mathrm{mg}$ ) is safe for intravitreal injection in rabbit eyes, suggesting its future potential application in uveitis. A higher dose of intravitreal natalizumab resulted in damage to the photoreceptor synaptic terminals and inner nuclear layer in the retina, although no systemic side effect was noted [37]. Intravitreal injections of integrin inhibitors may only target immune cells locally at the site of inflammation and vascular permeability breakdowns, a localized approach that may cause fewer systemic adverse side effects of concern. It may therefore be a potential therapeutic strategy for future studies.

Several in vivo EAU studies have demonstrated capability of anti-ICAM-1 Ab and antiLFA- $1 \mathrm{Ab}$ to ameliorate clinical severity in different EAU animal models but had no effect on experimental melanin-induced uveitis [38-41]. These indicated that ICAM-1/LFA-1 pathways are primarily involved in Th1-dominant uveitis, but do not have a role in cancerassociated uveitis. Blocking $\alpha 4$ also partially suppress uveitogenic leukocyte activation, indicating the role for other CAMs [40]. In vivo studies demonstrated that the distribution of other cell adhesion molecules such as P-selectin, E-selectin, and PECAM-1 increased progressively on the retinal microvascular endothelium alongside the development of EAU $[9,24]$. P-selectin and E-selectin were reported to be preferentially up-regulated at the retinal venules, which are the main site of leukocyte extravasation [42]. In a model of acute anterior uveitis, endotoxin-induced uveitis (EIU), it was demonstrated that blocking P-selectin and E-selectin was able to reduce leukocyte infiltration to the eye [43-45]. It has also been reported that rolling and recruitment of Th1-cell transmigration across the BRB is preferentially mediated by PSGL-1:P/E-selectin interactions in EAU [42]. The results are summarized in Table 1.

Table 1. Anti-adhesion molecule-based therapy for experimental autoimmune uveitis.

\begin{tabular}{|c|c|c|}
\hline Studies & Molecule and Animal Model & Outcome \\
\hline Rosenbaum et al. [38] & $\begin{array}{l}\text { Ab to LFA-1 (CD11a/CD18) and ICAM-1 } \\
\text { (iv) in rabbit model of uveitis. }\end{array}$ & $\begin{array}{l}\text { Anti-CD18 Ab effectively reduced cellular infiltration } \\
\text { if injected after } 24 \mathrm{~h} \text { of induction. Anti-CD11a Ab was } \\
\text { effective only in the IL-1-induced model. Anti-ICAM-1 } \\
\text { Ab was ineffective. }\end{array}$ \\
\hline Uchio et al. [39] & $\begin{array}{l}\text { Anti-ICAM-1 Ab or anti-LFA- } 1 \alpha \text { chain } \\
\mathrm{Ab} \text { (iv) consecutively after EAU } \\
\text { induction in rat. }\end{array}$ & $\begin{array}{l}\text { The development of EAU could be completely } \\
\text { prevented by anti-ICAM- } 1 \text { Ab but partially by } \\
\text { anti-LFA- } 1 \alpha \text { chain Ab. }\end{array}$ \\
\hline Martin et al. [40] & $\begin{array}{l}\alpha 4 \text { active peptide inhibitor (ip) was } \\
\text { administered to classical and adoptive } \\
\text { transferred B10.RIII EAU mice serially at } \\
\text { afferent and efferent phase of disease. }\end{array}$ & $\begin{array}{l}\text { Treatment at afferent and efferent phase has a similar } \\
\text { extent of disease downregulation, however; it did not } \\
\text { ablate the disease fully. Repeated injections can reduce } \\
\text { the disease scores further. }\end{array}$ \\
\hline Smith et al. [41] & $\begin{array}{l}\text { Anti-ICAM-1 Ab (ip) sequentially after } \\
\text { induction of EMIU. }\end{array}$ & Failed to suppress leukocyte infiltration. \\
\hline & \multicolumn{2}{|c|}{ Ab: antibody; EMIU: experimental melanin-induced uveitis; ip: intraperitoneal injection; iv: intravenous injection. } \\
\hline & \multicolumn{2}{|c|}{$\begin{array}{l}\text { The CAMs that are expressed on the leukocytes, such as VLA- } 4 \text { and LFA- } 1 \text {, are } \\
\text { upregulated throughout the course of EAU and if suppressed, are believed to downregulate } \\
\text { EAU via decreasing uveitogenic cell transmigration across the BRB. The CAMs expressed } \\
\text { at the vascular endothelium site are P-selectin, E-selectin, ICAM-1, and VCAM- } 1 \text {. Blocking } \\
\text { P-selectin and E-selectin interferes with leukocyte adherence to the vascular endothelium. } \\
\text { Hence, they are more important at the disease initiation phase than during the chronic } \\
\text { phase. In later phases of disease, suppression of ICAM- } 1 \text { and VCAM-1 becomes more } \\
\text { important to prevent structural damage of the retina resulting from continuous leukocyte } \\
\text { transmigration into the eye. }\end{array}$} \\
\hline
\end{tabular}




\subsection{Role of Adhesion Molecules in NIU}

The ICAM-1/LFA-1 and VCAM-1/VLA-4 are the main pathways reportedly involved in uveitis development in the literature. There is direct evidence of VCAM- 1 as well as ICAM-1/LFA involvement in uveitis development, as an increased expression was detected in iris biopsies from patients relative to controls [46]. In NIU patients, peripheral soluble ICAM-1 (sICAM-1) was reported to be a potential biomarker for disease relapse and activity but not sVCAM-1 [47-52]. However, contradictory data also reported that sICAM-1 and sVCAM-1 were not associated with active uveitis specifically related to Behçet's disease (BD) patients, and that there was only an association of sICAM-1 with the systemic activity [53]. Nevertheless, genetic studies have indicated that ICAM-1 (rs5498) is a susceptible locus for the development of BD-associated uveitis [54]. In other uveitis etiologies, however, there was evidence of other adhesion molecule involvement. For example, in patients with sympathetic ophthalmia, the expression of VLA-4, VLA-5, VCAM-1, ICAM-1, and CD44 in the peripheral blood was significantly increased in acute inflammation compared to either the disease resolution phase or normal eyes [20]. A previous study published by Haznedaroglu revealed increased levels of both sE-selectin and sP-selectin in BD patients [55]. In BD patients presenting retinal vasculitis, however, only sE-selectin and s-ICAM-1 serum levels were significantly increased [56]. In addition, it has been reported that sL-selectin from the polymorphonuclear leukocytes (PMN) decreased significantly following BD-associated uveitis flare-ups, whereas the level of Mac-1 ( $\alpha_{M} \beta 2, C D 1$ lb/CD18) remained stable [57].

To summarize, the data regarding CAMs in human uveitis are limited, with a lot of studies having been conducted several years ago. However, there is indirect evidence that ICAM-1, VCAM-1, P-selectin, and E-selectin in their soluble forms in the peripheral blood from patients are reported to be elevated compared to controls. ICAM-1 has been reported in several uveitis entities, particularly BD and sympathetic ophthalmia. It is likely that the ICAM-1 pathway plays a fundamental role in active uveitis but in different clinical presentations of uveitis. For example, in retinal vasculitis, the involvement of additional selectin families may be critical. Future studies are required to clarify how CAMs, including integrins, participate in different clinical presentations of uveitis, for example, chorioretinitis, diffuse retinitis, vasculitis, scleritis, and panuveitis, in order to develop a more personalized therapeutic approach.

\subsection{Clinical Trials of Anti-Adhesion Molecule Therapy for NIU}

There has been only one study developed to assess the safety and efficacy of an antiCAM-based therapy for NIU as summarized in Table 2. A case report also demonstrated a downregulation of uveitis clinical activity by natalizumab ( $\alpha 4 \beta 1$-targeted) in treating intermediate uveitis related to multiple sclerosis at one year [58]. Another case report has illustrated that Vedolizumab ( $\alpha 4 \beta 7$-targeted) therapy is able to clinically control uveitis associated with inflammatory bowel disease [59].

Table 2. Integrin based therapy for non-infectious uveitis (NIU).

\begin{tabular}{|c|c|c|}
\hline Clinical Trial & Receptor and Mechanism & Outcome \\
\hline $\begin{array}{l}\text { An open-label, prospective, } \\
\text { noncomparative phase I/II clinical trial } \\
\text { (ClinicalTrials.gov number, } \\
\text { NCT00280826.) [60] }\end{array}$ & $\begin{array}{l}\text { Weekly subcutaneous Efalizumab (a } \\
\text { humanized form of a murine IgG1 } \\
\text { antibody to CD11a, the } \alpha \text { subunit of } \\
\text { LFA-1, Raptiva; Genentech Inc., San } \\
\text { Francisco, CA, USA) treatment for } 16 \\
\text { weeks for patients with macular edema } \\
\text { secondary to NIU. }\end{array}$ & $\begin{array}{l}\text { Improvement in uveitis severity and } \\
\text { macular edema. } \\
\text { Upregulation of CD56 bright regulatory } \\
\text { NK cell population in the peripheral } \\
\text { blood. } \\
\text { Side effects: neutropenia (17\%) and } \\
\text { headache ( } 50 \%) \text {, resolved without } \\
\text { sequelae. Efalizumab was taken off the } \\
\text { market due to side effect of progressive } \\
\text { multifocal leukoencephalopathy (PML). }\end{array}$ \\
\hline
\end{tabular}


It is unfortunate that subcutaneous Efalizumab therapy increased the risk of PML, as illustrated by natalizumab (monoclonal antibody to integrin $\alpha 4 \beta 7$ and $\alpha 4 \beta 1$ ) in treating multiple sclerosis. On the other hand, the Efalizumab study illustrated a proof-of-concept that, as observed in EAU, inhibitor to LFA-1 is able to ameliorate the clinical severity of the disease. The route of administration of CAM inhibitors might need to be taken into consideration for future studies.

\subsection{Efficacy of Adhesion Molecule-Based Therapy in Other Retinal Disorders}

Adhesion molecule inhibitors have also been used purposefully in other retinal disorders. For example, Volociximab (M200, Ophthotech Corporation, New York, NY, USA, now Iveric Bio), a chimeric $\mathrm{mAb}$ to $\alpha 5 \beta 1$ integrin, has been applied to treat choroidal neovascularization resulting from age-related macular degeneration (AMD) [61] with no side effects in dose escalation studies when it was administered intravitreally in combination with ranibizumab for enhancing an anti-permeability effect in a phase I open-labeled trial. The trial revealed a best corrected visual acuity (BCVA) gain of 10.8 letters at nine weeks. However, the effect was not distinguishable from ranibizumab (ClinicalTrials.gov Identifier: NCT00782093) [62,63]. Risuteganib (Luminate, Allegro Ophthalmics, Capistrano, CA, USA) is a small peptide targeting multiple integrins $(\alpha \mathrm{V} \beta 3, \alpha \mathrm{V} \beta 5, \alpha 5 \beta 1$, and $\alpha 5 \beta 3)$. In phase II AMD studies adopting the intravitreal administration, $48 \%$ of patients gained $\geq 8$ Early Treatment Diabetic Retinopathy Study (ETDRS) letters. BCVA from baseline to week 28 in the risuteganib arm had no severe adverse drug reaction (ClinicalTrials.gov Identifier: NCT03626636) [64]. THR-687 (Oxurion, Leuven, Belgium) is another pan integrin receptor antagonist targeting $\alpha \mathrm{V} \beta 3, \alpha \mathrm{V} \beta 5$, and $\alpha 5 \beta 1$ [65]. In an open-label, multi-center, single dose escalation phase I study for diabetic macular edema (DME) patients who responded to prior anti-VEGF and/or corticosteroid, THR-687 intravitreal injections demonstrated a BCVA gain of 11.2 letters at week 2, and a lasting effect until month 3 with no toxicities or serious adverse events being noticed (ClinicalTrials.gov Identifier: NCT03666923) [66]. SF-0166 (SciFluor Life Science, Waltham, MA, USA) is a topical eyedrop of small molecule inhibitor of integrin $\alpha \mathrm{V} \beta 3$. Evidence of its biologic function was demonstrated by central retinal thickness (CRT) reduction in 38\% of DME patients at day 28 of use in a phase I/II prospective clinical trial (ClinicalTrials.gov Identifier: NCT02914613) [67]. In AMD and DME patients, by targeting functional arginine-glycine-aspartic acid (RGD) integrin receptors, collagen integrin receptors, and laminin integrin receptors [68], effects were demonstrated for interfering vitreo-retinal interphase $(\alpha 3 \beta 1)$, anti-angiogenesis $(\alpha \mathrm{V} \beta 3$, $\alpha \mathrm{V} \beta 5$, and $\alpha 5 \beta 1$ ), and inhibiting astrocyte apoptosis, which contributes to vascular leakage in DR ( $\alpha$ v 35$)$ [69], and promising clinical effects could be observed in preclinical and early clinical studies.

In conclusion, inhibition via targeting CAMs intravitreally in other retinal disorders such as AMD and DME illustrated the potential to serve as primary or adjunct therapy to anti-vascular endothelial growth factor agents. Nevertheless, no serious adverse events such as PML or JC virus infection were reported in these preliminary studies. This indicates that careful local administration of CAM-based therapy for uveitis patients may be a direction for future studies.

\section{Conclusions}

It has been demonstrated in proof-of-concept studies that leukocyte-specific, CAMtargeted therapy in animal studies and clinical trials can prevent immune cell migration/infiltration and reduce clinical severity (Figure 2). However, the concerns of serious systemic side effects hinder specific use of CAM-based therapies in uveitis. From CAMbased therapies attempted in AMD and DME treatment, it is likely that local intravitreal and topical eye drop treatments may exert their biological function and optimal outcomes, thereby avoiding any systemic adverse effects. In EAU studies, topical GW559090 targeting $\alpha 4 \beta 1$ has been shown to reduce EAU severity scores [35]. In addition, intravitreal injection of natalizumab demonstrated no systemic toxicities in vivo [37]. These studies 
further confirmed that these topical or intravitreally delivered drugs entered the eye and were effective locally at inflamed areas where the endothelium integrity was impaired. Currently, there is an immense unmet clinical need for new therapies to address reducing treatment burden and suboptimal outcomes to improve our current standard of care of NIU by using corticosteroid and other immunosuppressants. CAM inhibitors reduce leukocyte migration, contributing to an anti-inflammatory milieu in the retina, and may have the potential to address the treatment burden as an adjunct therapy, which requires further study. Furthermore, the data described in this review suggest that a more personalized medicine approach should identify the predominance of Th1 or Th17 involvement, which would then predict a localized targeting of ICAM-1/LFA-1 or VCAM-1/VLA-4 pathways, respectively. Similarly, if retinal vasculitis is involved, P-selectin or E-selectin directed therapy could be considered. However, to reach this stage, a better understanding of the molecular pathways involved is required, as well as a further in-depth patient stratification.
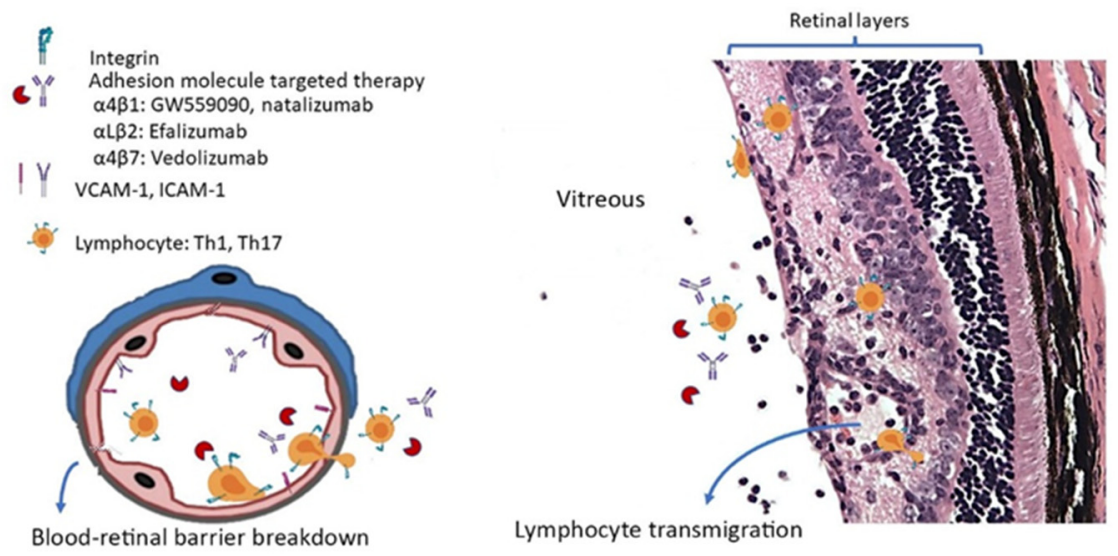

Figure 2. A schematic figure illustrating how adhesion molecules are involved in the process of leukocyte transmigration in uveitis and the current adhesion molecule targeted therapy being used in experimental autoimmune uveitis and non-infectious uveitis.

Author Contributions: Y.-H.C. wrote the manuscript; Y.-H.C., M.E., S.L. and V.L.C. edited the manuscript. All authors have read and agreed to the published version of the manuscript.

Funding: The research was funded by Chang Gung Memorial Hospital, grant number CMRPG5D0041.

Institutional Review Board Statement: Not applicable.

Informed Consent Statement: Not applicable.

Data Availability Statement: Not applicable.

Conflicts of Interest: The authors declare no conflict of interest or disclosures.

\section{References}

1. Caspi, R.R. A look at autoimmunity and inflammation in the eye. J. Clin. Investig. 2010, 120, 3073-3083. [CrossRef]

2. Forrester, J.V.; Kuffova, L.; Dick, A.D. Autoimmunity, Autoinflammation, and Infection in Uveitis. Am. J. Ophthalmol. 2018, 189, 77-85. [CrossRef]

3. Chu, D.S.; Johnson, S.J.; Mallya, U.G.; Davis, M.R.; Sorg, R.A.; Duh, M.S. Healthcare costs and utilization for privately insured patients treated for non-infectious uveitis in the USA. J. Ophthalmic Inflamm. Infect. 2013, 3, 64. [CrossRef]

4. García-Aparicio, Á.; García de Yébenes, M.J.; Otón, T.; Muñoz-Fernández, S. Prevalence and Incidence of Uveitis: A Systematic Review and Meta-analysis. Ophthalmic Epidemiol. 2021, 28, 461-468. [CrossRef]

5. Egwuagu, C.E.; Alhakeem, S.A.; Mbanefo, E.C. Uveitis: Molecular Pathogenesis and Emerging Therapies. Front. Immunol. 2021, 12, 623725. [CrossRef] [PubMed]

6. Hyun, Y.M.; Lefort, C.T.; Kim, M. Leukocyte integrins and their ligand interactions. Immunol. Res. 2009, 45, 195-208. [CrossRef] [PubMed]

7. Hill, T.A.; Stanford, M.R.; Graham, E.M.; Dumonde, D.C.; Brown, K.A. A new method for studying the selective adherence of blood lymphocytes to the microvasculature of human retina. Investig. Ophthalmol. Vis. Sci. 1997, 38, 2608-2618. 
8. Harjunpää, H.; Llort Asens, M.; Guenther, C.; Fagerholm, S.C. Cell Adhesion Molecules and Their Roles and Regulation in the Immune and Tumor Microenvironment. Front. Immunol. 2019, 10, 1078. [CrossRef] [PubMed]

9. $\mathrm{Xu}, \mathrm{H} . ;$ Forrester, J.V.; Liversidge, J.; Crane, I.J. Leukocyte trafficking in experimental autoimmune uveitis: Breakdown of blood-retinal barrier and upregulation of cellular adhesion molecules. Investig. Ophthalmol. Vis. Sci. 2003, 44, 226-234. [CrossRef]

10. Dustin, M.L. Integrins and Their Role in Immune Cell Adhesion. Cell 2019, 177, 499-501. [CrossRef]

11. Butzkueven, H.; Kappos, L.; Wiendl, H.; Trojano, M.; Spelman, T.; Chang, I.; Kasliwal, R.; Jaitly, S.; Campbell, N.; Ho, P.R.; et al. Long-term safety and effectiveness of natalizumab treatment in clinical practice: 10 years of real-world data from the Tysabri Observational Program (TOP). J. Neurol. Neurosurg. Psychiatry 2020, 91, 660-668. [CrossRef]

12. Engelhardt, B.; Laschinger, M.; Schulz, M.; Samulowitz, U.; Vestweber, D.; Hoch, G. The development of experimental autoimmune encephalomyelitis in the mouse requires alpha4-integrin but not alpha4beta7-integrin. J. Clin. Investig. 1998, 102, 2096-2105. [CrossRef]

13. Döring, A.; Pfeiffer, F.; Meier, M.; Dehouck, B.; Tauber, S.; Deutsch, U.; Engelhardt, B. TET inducible expression of the $\alpha 4 \beta 7-$ integrin ligand MAdCAM-1 on the blood-brain barrier does not influence the immunopathogenesis of experimental autoimmune encephalomyelitis. Eur. J. Immunol. 2011, 41, 813-821. [CrossRef]

14. Takatsu, N.; Hisabe, T.; Higashi, D.; Ueki, T.; Matsui, T. Vedolizumab in the Treatment of Ulcerative Colitis: An Evidence-Based Review of Safety, Efficacy, and Place of Therapy. Core Evid. 2020, 15, 7-20. [CrossRef] [PubMed]

15. Luzentales-Simpson, M.; Pang, Y.C.F.; Zhang, A.; Sousa, J.A.; Sly, L.M. Vedolizumab: Potential Mechanisms of Action for Reducing Pathological Inflammation in Inflammatory Bowel Diseases. Front. Cell Dev. Biol. 2021, 9, 612830. [CrossRef] [PubMed]

16. Jelcic, I.; Jelcic, I.; Faigle, W.; Sospedra, M.; Martin, R. Immunology of progressive multifocal leukoencephalopathy. J. Neurovirol. 2015, 21, 614-622. [CrossRef] [PubMed]

17. Damle, N.K.; Klussman, K.; Linsley, P.S.; Aruffo, A. Differential costimulatory effects of adhesion molecules B7, ICAM-1, LFA-3, and VCAM-1 on resting and antigen-primed CD4+ T lymphocytes. J. Immunol. 1992, 148, 1985-1992.

18. Wakefield, D.; McCluskey, P.; Palladinetti, P. Distribution of lymphocytes and cell adhesion molecules in iris biopsy specimens from patients with uveitis. Arch. Ophthalmol. 1992, 110, 121-125. [CrossRef]

19. Whitcup, S.M.; Chan, C.C.; Li, Q.; Nussenblatt, R.B. Expression of cell adhesion molecules in posterior uveitis. Arch. Ophthalmol. 1992, 110, 662-666. [CrossRef]

20. Kuppner, M.C.; Liversidge, J.; McKillop-Smith, S.; Lumsden, L.; Forrester, J.V. Adhesion molecule expression in acute and fibrotic sympathetic ophthalmia. Curr. Eye Res. 1993, 12, 923-934. [CrossRef]

21. Qasem, A.R.; Bucolo, C.; Baiula, M.; Spartà, A.; Govoni, P.; Bedini, A.; Fascì, D.; Spampinato, S. Contribution of alpha4beta1 integrin to the antiallergic effect of levocabastine. Biochem. Pharmacol. 2008, 76, 751-762. [CrossRef]

22. Haber, S.L.; Benson, V.; Buckway, C.J.; Gonzales, J.M.; Romanet, D.; Scholes, B. Lifitegrast: A novel drug for patients with dry eye disease. Ther. Adv. Ophthalmol. 2019, 11, 70366. [CrossRef]

23. White, D.E.; Zhao, Y.; Ogundele, A.; Fulcher, N.; Acs, A.; Moore-Schiltz, L.; Karpecki, P.M. Real-World Treatment Patterns of Cyclosporine Ophthalmic Emulsion And Lifitegrast Ophthalmic Solution Among Patients With Dry Eye. Clin. Ophthalmol. 2019, 13, 2285-2292. [CrossRef]

24. Parnaby-Price, A.; Stanford, M.R.; Biggerstaff, J.; Howe, L.; Whiston, R.A.; Marshall, J.; Wallace, G.R. Leukocyte trafficking in experimental autoimmune uveitis in vivo. J. Leukoc. Biol. 1998, 64, 434-440. [CrossRef]

25. Devine, L.; Lightman, S.L.; Greenwood, J. Role of LFA-1, ICAM-1, VLA-4 and VCAM-1 in lymphocyte migration across retinal pigment epithelial monolayers in vitro. Immunology 1996, 88, 456-462. [CrossRef] [PubMed]

26. Greenwood, J.; Wang, Y.; Calder, V.L. Lymphocyte adhesion and transendothelial migration in the central nervous system: The role of LFA-1, ICAM-1, VLA-4 and VCAM-1. off. Immunology 1995, 86, 408-415. [PubMed]

27. Platts, K.E.; Benson, M.T.; Rennie, I.G.; Sharrard, R.M.; Rees, R.C. Cytokine modulation of adhesion molecule expression on human retinal pigment epithelial cells. Investig. Ophthalmol. Vis. Sci. 1995, 36, 2262-2269.

28. Dewispelaere, R.; Lipski, D.; Foucart, V.; Bruyns, C.; Frère, A.; Caspers, L.; Willermain, F. ICAM-1 and VCAM-1 are differentially expressed on blood-retinal barrier cells during experimental autoimmune uveitis. Exp. Eye Res. 2015, 137, 94-102. [CrossRef]

29. Whitcup, S.M.; DeBarge, L.R.; Caspi, R.R.; Harning, R.; Nussenblatt, R.B.; Chan, C.C. Monoclonal antibodies against ICAM1 (CD54) and LFA-1 (CD11a/CD18) inhibit experimental autoimmune uveitis. Clin. Immunol. Immunopathol. 1993, 67, 143-150. [CrossRef]

30. Tamatani, T.; Kitamura, F.; Kuida, K.; Shirao, M.; Mochizuki, M.; Suematsu, M.; Schmid-Schönbein, G.W.; Watanabe, K.; Tsurufuji, S.; Miyasaka, M. Characterization of rat LECAM-1 (L-selectin) by the use of monoclonal antibodies and evidence for the presence of soluble LECAM-1 in rat sera. Eur. J. Immunol. 1993, 23, 2181-2188. [CrossRef]

31. Ke, Y.; Sun, D.; Zhang, P.; Jiang, G.; Kaplan, H.J.; Shao, H. Suppression of established experimental autoimmune uveitis by anti-LFA-1alpha Ab. Investig. Ophthalmol. Vis. Sci. 2007, 48, 2667-2675. [CrossRef]

32. Bharadwaj, A.S.; Schewitz-Bowers, L.P.; Wei, L.; Lee, R.W.; Smith, J.R. Intercellular adhesion molecule 1 mediates migration of Th1 and Th17 cells across human retinal vascular endothelium. Investig. Ophthalmol. Vis. Sci. 2013, 54, 6917-6925. [CrossRef]

33. Ishida, W.; Harada, Y.; Fukuda, K.; Taguchi, O.; Yagita, H.; Fukushima, A. Inhibition of very late antigen-4 and leukocyte function-associated antigen-1 in experimental autoimmune uveoretinitis. Clin. Immunol. 2014, 153, 136-144. [CrossRef] [PubMed]

34. Guimaraes de Souza, R.; Yu, Z.; Stern, M.E.; Pflugfelder, S.C.; de Paiva, C.S. Suppression of Th1-Mediated Keratoconjunctivitis Sicca by Lifitegrast. J. Ocul. Pharmacol. Ther. Off. J. Assoc. Ocul. Pharmacol. Ther. 2018, 34, 543-549. [CrossRef] [PubMed] 
35. Chen, Y.H.; Eskandarpour, M.; Zhang, X.; Galatowicz, G.; Greenwood, J.; Lightman, S.; Calder, V. Small-molecule antagonist of VLA-4 (GW559090) attenuated neuro-inflammation by targeting Th17 cell trafficking across the blood-retinal barrier in experimental autoimmune uveitis. J. Neuroinflamm. 2021, 18, 49. [CrossRef] [PubMed]

36. Zhang, X.; Jiang, S.; Manczak, M.; Sugden, B.; Adamus, G. Phenotypes of T cells infiltrating the eyes in autoimmune anterior uveitis associated with EAE. Investig. Ophthalmol. Vis. Sci. 2002, 43, 1499-1508.

37. Chawla, R.; Nath, M.; Moksha, L.; Nag, T.C.; Velpandian, T. An experimental study to evaluate safety/toxicity of intravitreal natalizumab. Indian J. Ophthalmol. 2018, 66, 1441-1445. [CrossRef] [PubMed]

38. Rosenbaum, J.T.; Boney, R.S. Efficacy of antibodies to adhesion molecules, CD11a or CD18, in rabbit models of uveitis. Curr. Eye Res. 1993, 12, 827-831. [CrossRef]

39. Uchio, E.; Kijima, M.; Tanaka, S.; Ohno, S. Suppression of experimental uveitis with monoclonal antibodies to ICAM-1 and LFA-1. Investig. Ophthalmol. Vis. Sci. 1994, 35, 2626-2631.

40. Martin, A.P.; de Moraes, L.V.; Tadokoro, C.E.; Commodaro, A.G.; Urrets-Zavalia, E.; Rabinovich, G.A.; Urrets-Zavalia, J.; Rizzo, L.V.; Serra, H.M. Administration of a peptide inhibitor of alpha4-integrin inhibits the development of experimental autoimmune uveitis. Investig. Ophthalmol. Vis. Sci. 2005, 46, 2056-2063. [CrossRef]

41. Smith, J.R.; O’Rourke, L.M.; Becker, M.D.; Cao, M.; Williams, K.A.; Planck, S.R.; Rosenbaum, J.T. Anti-rat ICAM-1 antibody does not influence the course of experimental melanin-induced uveitis. Curr. Eye Res. 2000, 21, 906-912. [CrossRef] [PubMed]

42. Xu, H.; Manivannan, A.; Jiang, H.R.; Liversidge, J.; Sharp, P.F.; Forrester, J.V.; Crane, I.J. Recruitment of IFN-gamma-producing (Th1-like) cells into the inflamed retina in vivo is preferentially regulated by P-selectin glycoprotein ligand 1:P/E-selectin interactions. J. Immunol. 2004, 172, 3215-3224. [CrossRef] [PubMed]

43. Whitcup, S.M.; Kozhich, A.T.; Lobanoff, M.; Wolitzky, B.A.; Chan, C.C. Blocking both E-selectin and P-selectin inhibits endotoxininduced leukocyte infiltration into the eye. Clin. Immunol. Immunopathol. 1997, 83, 45-52. [CrossRef] [PubMed]

44. Miyamoto, K.; Ogura, Y.; Hamada, M.; Nishiwaki, H.; Hiroshiba, N.; Tsujikawa, A.; Mandai, M.; Suzuma, K.; Tojo, S.J.; Honda, Y. In vivo neutralization of P-selectin inhibits leukocyte-endothelial interactions in retinal microcirculation during ocular inflammation. Microvasc. Res. 1998, 55, 230-240. [CrossRef] [PubMed]

45. Suzuma, I.; Mandai, M.; Suzuma, K.; Ishida, K.; Tojo, S.J.; Honda, Y. Contribution of E-selectin to cellular infiltration during endotoxin-induced uveitis. Investig. Ophthalmol. Vis. Sci. 1998, 39, 1620-1630.

46. La Heij, E.; Kuijpers, R.W.; Baarsma, S.G.; Kijlstra, A.; van der Weiden, M.; Mooy, C.M. Adhesion molecules in iris biopsy specimens from patients with uveitis. Br. J. Ophthalmol. 1998, 82, 432-437. [CrossRef]

47. Zaman, A.G.; Edelsten, C.; Stanford, M.R.; Graham, E.M.; Ellis, B.A.; Direskeneli, H.; D'Cruz, D.P.; Hughes, G.R.; Dumonde, D.C.; Wallace, G.R. Soluble intercellular adhesion molecule-1 (sICAM-1) as a marker of disease relapse in idiopathic uveoretinitis. Clin. Exp. Immunol. 1994, 95, 60-65. [CrossRef]

48. Arocker-Mettinger, E.; Steurer-Georgiew, L.; Steurer, M.; Huber-Spitzy, V.; Hoelzl, E.; Grabner, G.; Kuchar, A. Circulating ICAM-1 levels in serum of uveitis patients. Curr. Eye Res. 1992, 11, 161-166. [CrossRef]

49. Pereira-Neves, L.; Palma-Carlos, M.L.; Soares, I.; Pereira-Santos, M.C.; Ganhao, F.; Palma-Carlos, A.G. Soluble ICAM-1 and VCAM-1 serum levels in uveitis. Allerg. Immunol. 1996, 28, 302-306.

50. Klok, A.M.; Luyendijk, L.; Zaal, M.J.; Rothova, A.; Kijlstra, A. Soluble ICAM-1 serum levels in patients with intermediate uveitis. Br. J. Ophthalmol. 1999, 83, 847-851. [CrossRef]

51. Uchio, E.; Matsumoto, T.; Tanaka, S.I.; Ohno, S. Soluble intercellular adhesion molecule-1 (ICAM-1), CD4, CD8 and interleukin-2 receptor in patients with Behçet's disease and Vogt-Koyanagi-Harada's disease. Clin. Exp. Rheumatol. 1999, 17, 179-184. [PubMed]

52. Martin, C.M.; Lacomba, M.S.; Molina, C.I.; Chamond, R.R.; Galera, J.M.; Estevez, E.C. Levels of soluble ICAM-1 and soluble IL-2R in the serum and aqueous humor of uveitis patients. Curr. Eye Res. 2000, 20, 287-292. [CrossRef]

53. Verity, D.H.; Wallace, G.R.; Seed, P.T.; Kanawati, C.A.; Ayesh, I.; Holland-Gladwish, J.; Stanford, M.R. Soluble adhesion molecules in Behcet's disease. Ocul. Immunol. Inflamm. 1998, 6, 81-92. [CrossRef] [PubMed]

54. Kim, S.J.; Lee, S.; Park, C.; Seo, J.S.; Kim, J.I.; Yu, H.G. Targeted resequencing of candidate genes reveals novel variants associated with severe Behçet's uveitis. Exp. Mol. Med. 2013, 45, 49. [CrossRef]

55. Haznedaroglu, E.; Karaaslan, Y.; Büyükaşik, Y.; Koşar, A.; Ozcebe, O.; Haznedaroglu b, C.; Kirazli, E.; Dündar, S.V. Selectin adhesion molecules in Behçet's disease. Ann. Rheum. Dis. 2000, 59, 61-63. [CrossRef] [PubMed]

56. Lee, M.T.; Hooper, L.C.; Kump, L.; Hayashi, K.; Nussenblatt, R.; Hooks, J.J.; Detrick, B. Interferon-beta and adhesion molecules (E-selectin and s-intracellular adhesion molecule-1) are detected in sera from patients with retinal vasculitis and are induced in retinal vascular endothelial cells by Toll-like receptor 3 signalling. Clin. Exp. Immunol. 2007, 147, 71-80. [CrossRef]

57. Kaku, H.; Mizukawa, H.; Kishi, I.; Yanagida, T.; Inaba, G. Peripheral leukocyte adhesion molecules in patients of Behçet's disease associated with active ocular lesions. Ryumachi 1994, 34, 608-615.

58. Roemer, S.; Bissig, A.; Rocca, A.; Du Pasquier, R.; Guex-Crosier, Y. Efficacy of Natalizumab in Intermediate Uveitis Related to Multiple Sclerosis: A Case Report. Klin. Monbl. Augenheilkd. 2018, 235, 476-477. [CrossRef]

59. Fleisher, M.; Marsal, J.; Lee, S.D.; Frado, L.E.; Parian, A.; Korelitz, B.I.; Feagan, B.G. Effects of Vedolizumab Therapy on Extraintestinal Manifestations in Inflammatory Bowel Disease. Dig. Dis. Sci. 2018, 63, 825-833. [CrossRef]

60. Faia, L.J.; Sen, H.N.; Li, Z.; Yeh, S.; Wroblewski, K.J.; Nussenblatt, R.B. Treatment of inflammatory macular edema with humanized anti-CD11a antibody therapy. Investig. Ophthalmol. Vis. Sci. 2011, 52, 6919-6924. [CrossRef] 
61. Ramakrishnan, V.; Kuppermann, B.D.; Bhaskar, V.; Wales, P.; Hagemann, L.F.; Marques, L.; Carvalho, R.P.d.; Wong, C.G.; Murray, R. F200, a Fab Derivative of M200 (Volociximab; Anti-A5ß1), Is a Potent Inhibitor of Angiogenesis in a Rabbit Model of Choroidal Neovascularization. Investig. Ophthalmol. Vis. Sci. 2005, 46, 465.

62. Ishikawa, M.; Jin, D.; Sawada, Y.; Abe, S.; Yoshitomi, T. Future therapies of wet age-related macular degeneration. J. Ophthalmol. 2015, 2015, 138070. [CrossRef]

63. Ho, A.C.; Regillo, C.D. The future of neovascular age-related macular degeneration. In Age-Related Macular Degeneration Diagnosis and Treatment, 1st ed.; Ho, A.C., Ed.; Springer: New York, NY, USA, 2011; pp. 135-153.

64. Boyer, D.S.; Gonzalez, V.H.; Kunimoto, D.Y.; Maturi, R.K.; Roe, R.H.; Singer, M.A.; Xavier, S.; Kornfield, J.A.; Kuppermann, B.D.; Quiroz-Mercado, H.; et al. Safety and Efficacy of Intravitreal Risuteganib for Non-Exudative AMD: A Multicenter, Phase 2a, Randomized, Clinical Trial. Ophthalmic Surg. Lasers Imaging Retin. 2021, 52, 327-335. [CrossRef]

65. Hu, T.T.; Vanhove, M.; Porcu, M.; Van Hove, I.; Van Bergen, T.; Jonckx, B.; Barbeaux, P.; Vermassen, E.; Feyen, J.H.M. The potent small molecule integrin antagonist THR-687 is a promising next-generation therapy for retinal vascular disorders. Exp. Eye Res. 2019, 180, 43-52. [CrossRef]

66. Khanani, A.M.; Patel, S.S.; Gonzalez, V.H.; Moon, S.J.; Jaffe, G.J.; Wells, J.A.; Kozma, P.; Dugel, P.U.; Maturi, R.K. Phase 1 Study of THR-687, a Novel, Highly Potent Integrin Antagonist for the Treatment of Diabetic Macular Edema. Ophthalmol. Sci. 2021, 1, 100040. [CrossRef]

67. Edwards, D.; Boyer, D.S.; Kaiser, P.K.; Heier, J.S.; Askew, B. First-in human study of SF0166 Topical Ophthalmic Solution in patients with diabetic macular edema. Investig. Ophthalmol. Vis. Sci. 2018, 59, 1961

68. Takada, Y.; Ye, X.; Simon, S. The integrins. Genome Biol. 2007, 8, 215. [CrossRef] [PubMed]

69. Gonzalez-Salinas, R.; Hernandez-Zimbron, L.F.; Gulias-Canizo, R.; Sanchez-Vela, M.A.; Ochoa-De La Paz, L.; Zamora, R.; Quiroz-Mercado, H. Current Anti-Integrin Therapy for Ocular Disease. Semin. Ophthalmol. 2018, 33, 634-642. [CrossRef] [PubMed] 